\title{
Marine Spatial Planning in the North Sea-Are National Policies and Legal Structures Compatible Enough? The Case of Norway and the Netherlands
}

\author{
Froukje Maria Platjouw
}

Research scientist, Norwegian Institute for Water Research (NIVA), Section for Water and Society, Gaustadalléen 23, 0349 Oslo, Norway

\begin{abstract}
Marine spatial planning is an important tool to achieve a more ecosystem-based governance approach to marine ecosystems. Marine ecosystems often transcend national jurisdictional boundaries, so the compatibility of national policies and legal structures are important prerequisites for transboundary marine spatial planning. This article explores marine spatial planning in the North Sea ecosystem and analyses whether national policies and legal structures in the Netherlands and Norway are compatible enough. Both countries have an extensive body of law regulating the different uses of the North Sea and have also developed integrated management approaches for 'their' respective parts of the North Sea. The article demonstrates that marine spatial planning in regional sea areas is complicated when national legal frameworks and governance structures and traditions are very different.
\end{abstract}

\section{Keywords}

transboundary marine spatial planning - laws and policies - North Sea - Norway The Netherlands - compatibility - EU Directives - OSPAR

\section{Introduction}

Marine spatial planning (MSP) is an important tool to achieve a more ecosystem-based governance approach to marine ecosystems. MSP is often described as 
an integrated, policy-based approach to the regulation, management and protection of the marine environment, including the allocation of space, which addresses the multiple, cumulative and potentially conflicting uses of the sea and thereby facilitates sustainable development. ${ }^{1}$

As a policy tool, MSP has clear benefits as it enables governments to plan and coordinate their different uses of the marine environment, and ideally, maintaining ecological integrity by regulating uses in ecologically important areas. However, successfully implementing MSP may be difficult, particularly in transboundary marine ecosystems.

Marine and coastal ecosystem dynamics can transcend administrative boundaries. MSP can facilitate transboundary planning towards wider regional or sea basin considerations. ${ }^{2}$ Nevertheless, activities in the marine environment can have impacts beyond their allotted areas of operation and beyond the planned area. Conflicts may arise among users when effects on the environment caused by one activity negatively impacts other activities. For example, sand extraction can lead to sedimentation in nearby fish-spawning grounds. Rationalizing such conflicts is part of the purpose of MSP. ${ }^{3}$

MSP is a neutral instrument for improved decision-making, providing a framework for arbitrating between human activities at sea and for managing their impact on the marine environment. MSP facilitates the balancing of sectoral interests with the aim of achieving sustainable use of marine resources and optimizing the use of marine space. ${ }^{4}$ Oceans and seas encompass highly complex ecosystems that often cross administrative borders. The world's oceans and seas are interlinked, and action taken in one marine area can have effects on other activities either in the same or adjacent areas. ${ }^{5}$ Schaefer and Barale (2011) argue that

1 MSPP consortium, 'Marine Spatial Planning Pilot: Final Report', available at http://www .abpmer.net/mspp/docs/finals/MSPFinal_report.pdf; accessed 13 October 2016.

2 P Gilliland and D Laffeley, 'Key elements and steps in the process of developing ecosystembased marine spatial planning' (2008) 35(5) Marine Policy 787-796, at p. 787.

3 AJ Gilbert et al., 'Marine spatial planning and Good Environmental Status: a perspective on spatial and temporal dimensions' (2015) 20(1) Ecology and Society 64, at p. 3. http://www .ecologyandsociety.org/vol2o/issi/art64/

4 N Schaefer and V Barale, 'Marine spatial planning: opportunities \& challenges in the framework of the EU integrated maritime policy' (2011) 15Journal of Coastal Conservation 237-245, at p. 238 .

5 Ibid. 
[c]oastal states sharing a common approach to the management of maritime areas, an approach that takes into account its own cross-border impacts, will find it easier to avoid conflicts between competing interests, to coordinate the use of limited space and resources for the greater benefit of all, and finally to reduce the economic costs of non-coordination. ${ }^{6}$

Transboundary cooperation is thus advanced as a necessary component of effective MSP, not only for the purpose of reducing user conflicts, but also for the sake of implementing an ecosystem-based approach. Flannery et al. (2014) conclude that

transboundary MSP is viewed, inter alia, as a process which allows for: greater integration and harmonisation between existing management frameworks to facilitate the implementation of an ecosystem-based approach; the protection of valuable ecosystem services; effective fisheries management; addressing marine pollution issues; the planning of crossborder Marine Protected Areas; and the selection of the most appropriate sites in the region for development. ${ }^{7}$

Though necessary, transboundary MSP is not easy to accomplish. Obviously, in marine ecosystems, planning efforts should be aligned with the geographies of ecosystems and resources, rather than only with jurisdictional territories. ${ }^{8}$ The challenge arises when authorities from different jurisdictions need to agree on potential patterns of marine uses across borders. This requires careful negotiations with regard to policy priorities and regulatory practices within each jurisdiction, leading to convergence on matters of mutual interest. Some kind of formal agreement may need to be drawn up, which may then be translated into the official plans of the administrations concerned. ${ }^{9}$ To attain these formal agreements, compatible legal structures and architectures play an important role.

Successful transboundary MSP depends on the willingness of coastal states to take into account each other's national policy priorities in exercising their

6 Ibid., p. 239.

7 W Flannery, AM O'Hagan, C O’Mahony, H Ritchie and S Twomey, 'Evaluating conditions for transboundary Marine Spatial Planning: challenges and opportunities on the island of Ireland' (2014) Marine Policy 86-95, http://dx.doi.org/10.1016/j.marpol.2014.07.021.

8 S Jay et al., 'Transboundary dimensions of marine spatial planning: Fostering inter-jurisdictional relations and governance' (2016) 65 Marine Policy 85-96, at p. 85 .

9 Ibid. 
sovereignty and sovereign rights, and adjust them towards common goals for the benefit of the whole region. ${ }^{10}$ The European Commission's Green Paper, 'Towards a future Maritime Policy for the Union: A European vision for the oceans and seas'll recognized that under the current legal circumstances, individual decisions on activities should be taken at a national or local level but that "a degree of commonality between the systems will be needed to ensure that decisions affecting the same ecosystem or cross-border activities [...] are dealt with in a coherent manner".12

The 2015 report of the European Union Committee of the House of Lords, entitled 'The North Sea under pressure: is regional marine cooperation the answer?' also drew attention to the concern over the different approaches by Member States to the implementation of single pieces of $\mathrm{E} U$ legislation. It was argued that "If the Dutch do it one way and the British do it another way, we are going to have chaos in the middle". ${ }^{3}$ The report stresses the need for guidance on the implementation of $\mathrm{EU}$ policies affecting the marine environment. In its recommendation number 8 , the report welcomes

the appointment of a European Commissioner responsible for both environmental policy and maritime affairs. An important priority for the new Commissioner should be to ensure that Eu legislation affecting the marine environment is consistent. We recommend that the Commission publish guidance for Member States on implementation of such legislation at national level, to improve consistency both between Member States and within the Member States. ${ }^{14}$

Indeed, a degree of convergence in policy and legislative arrangements across borders is a critical element of successful transboundary MSP. The more alike the policy and legislative structures and discourses in neighbouring jurisdictions, the more probable it is that transboundary planning will succeed. ${ }^{15}$

$10 \quad$ F Maes and A Cliquet, 'Marine Spatial Planning: Global and regional conventions and organizations' in: D Hassan, T Kuokkanen and N Soininen (eds), Transboundary Marine Spatial Planning and International Law (Routledge, Abingdon, 2015) 85-100, at p. 86.

11 European Commission, Green Paper: Towards a Future Maritime Policy for the Union: A European Vision for the Oceans and Seas, сом (2006) 275 final, 7 June, p. 34.

12 Maes and Cliquet 2015 (n 10).

13 House of Lords Committee, European Union Committee, The North Sea under Pressure: Is Regional Marine Co-operation the answer?, 1oth Report of Session 2014-15, House of Lords paper 137 (10 March 2015), at paras. 94-95.

14 Ibid., at paragraph 97.

15 Flannery et al. $2014\left(\mathrm{n}_{7}\right)$ at p. 89. 
More generally, Flannery et al. (2014) mention that a number of factors may influence the degree of convergence in neighbouring states. Firstly, policy and legislative convergence may arise as a result of the harmonising effect of international and supranational actors. For example, the process of Europeanisation has resulted in a degree of convergence across Eu Member States. ${ }^{16}$ Secondly, the existence of a network of well-developed transboundary institutions reduces transaction costs associated with transboundary planning and facilitates transboundary working. These institutions may be formal or informal alliances and include supranational institutions, such as OSPAR (spanning the North-East Atlantic). A network of transboundary institutions will mean that the key actors will know each other, they will have experience in transboundary cooperation and may have developed good working relations. ${ }^{17}$

This article analyses the possibilities for transboundary marine spatial planning in the North Sea ecosystem, with a particular focus on the policy and legislative divergence between Norway (a non-Eu member state) and the Netherlands. Marine spatial planning in the North Sea ecosystem is interesting because of the variation and divergence in MSP-related laws and policies in the different jurisdictions involved. The article starts with a short introduction of the North Sea ecosystem followed by an overview of some of the main Eu legal instruments aiming to regulate human activities in the North Sea while also attaining a certain level of environmental quality in the marine environment. Then the article will examine the Eu Maritime Spatial Planning Directive, its procedural requirements and its requirements with regard to the cooperation with non-EU neighbouring countries in regional sea areas. The final part of the article will present the Norwegian and Dutch approach to MSP and describe the different legal structures in these countries. The article also discusses the role of regional organizations, such as OSPAR, in providing a platform for regional cooperation in the North Sea.

\section{The North Sea}

While transboundary cooperation is viewed as a critical element of sustainable planning and development in shared marine regions, it is not possible to develop an ideal governance framework for transboundary planning initiatives. Transboundary initiatives need to be designed to suit the issue(s) at hand and

\footnotetext{
$16 \quad$ Ibid.

17 Ibid., at p. 90.
} 
to fit within the unique context of the region. ${ }^{18}$ This section provides a short introduction to the North Sea ecosystem, its ecological importance and human pressures.

The North Sea ecosystem is a semi-enclosed sea situated on the continental shelf of north-western Europe, in the Atlantic Ocean. It covers an area of about $750000 \mathrm{~km}^{2}$ and has an average depth of 90 meters, with depths not exceeding 700 meters $^{19}$ and is surrounded by densely populated, highly industrialised countries such as England, Scotland, Norway, Sweden, Denmark, Germany, the Netherlands, Belgium and France. The North Sea is characterised by its great ecological variety of habitats including fjords, estuaries, deltas, banks, beaches, sandbanks and mudflats, marshes, rocks and islands. ${ }^{20}$ The North Sea ecosystem is of a particular high ecological value because it is a highly complex and open marine ecosystem, shallow and rich in nutrients, that is "defined by a subtle interaction between climate, sea currents, nutrients, sediments, flora and fauna and human use". ${ }^{21}$ The North Sea is also of great socio-economic value and is actually one of the busiest seas in the world. Considerable pressure on the ecosystem is caused by inputs from industry, agriculture, and 184 million people in the catchment area. ${ }^{22}$ Impacts mainly derive from agriculture and recreation in the coastal zones; extensive fisheries; ${ }^{23}$ offshore industry; ${ }^{24}$ intense shipping use ${ }^{25}$ and growing aquaculture activities. ${ }^{26}$

18 Flannery et al. $2014(\mathrm{n} 7)$ at p. 88.

19 OSPAR Commission, 'Region II-Greater North Sea' available at http://www.ospar.org/ convention/the-north-east-atlantic/ii; accessed 13 October 2016.

$20 \quad$ Ibid.

21 Ministry of Infrastructure and the Environment, Policy Document on the North Sea 2009-2015 (22 December 2009) paragraph 2.9; OSPAR Commission, 'Quality Status Report 2010. Chapter 2: The North East Atlantic' available at http://qsr2010.ospar.org/ en/media/chapter_pdf/QSR_Cho2_EN.pdf; accessed 13 October 2016; see also European Environment Agency, The Changing Faces of Europe's Coastal areas (Office for Official Publications of the European Communities, 2006) 112.

22 M Walday and T Kroglund, Europe's Biodiversity-Biogeographical Regions and Seas. Seas around Europe: The North Sea-Bottom Trawling and Oil/Gas Exploitation (European Environment Agency, 2002).

23 OSPAR Commission, 'Quality Status Report 2010. Key Findings' available at http://qsr2010. ospar.org/en/media/content_pdf/choo/Keyfindings_EN.pdf; accessed 13 October 2016.

24 European Commission ( $\mathrm{n}$ 17); see also European Commission, 'Facing the Challenge of the Safety of Offshore Oil and Gas Activities' (Communication) Сом (2010) 560 final.

25 OSPAR Commission, 'Assessment of Impacts of Shipping on the marine environment' 8, available at http://qsr2010.ospar.org/media/assessments/poo440_Shipping_Assessment .pdf; accessed 13 October 2016.

$26 \quad$ Ibid. 
Over time, these pressures and impacts have caused a number of challenges. OSPAR's 2010 Quality Assessment Report identified a number of environmental problems that need to be addressed, including eutrophication, pollution, and unsustainable fishing. ${ }^{27}$ A number of industrial activities are likely to begin or increase in the North Sea in response to climate change. The coast of the Southern North Sea is susceptible to sea-level rise and erosion, so large-scale development of coastal defenses is likely, with an associated increase in pressure on seabed habitats from sand extraction for beach nourishment. The North Sea is also an attractive site for offshore energy generation from renewable sources. The long-term effects of these large-scale projects are not clear. ${ }^{28}$

To find the right balance between nature conservation and sustainable human use within this diverse and intensively used marine ecosystem is not an easy task. For the protection of the North Sea, the two most important conventions are the 1982 United Nations Convention on the Law of the Sea (LOSC), ${ }^{29}$ and the 1992 OSPar Convention for the Protection of the Marine Environment of the North-East Atlantic (OSPAR). ${ }^{30}$ Article 2 of the OSPAR Convention requires the Parties to the Convention to "take all possible steps to prevent and eliminate pollution and take the necessary measures to protect the maritime area against the adverse effects of human activities so as to safeguard human health and to conserve marine ecosystems and, when practicable, restore marine areas which have been adversely affected". ${ }^{31}$ The Parties are required to apply the precautionary principle and the polluter pays principle. ${ }^{32}$ Both Norway and the Netherlands have ratified the LOSC and the OSPAR Conventions.

\section{LOSC}

For transboundary MSP in the North Sea, the LOSC is of importance because of the provisions related to the different maritime zones and its requirements for regional cooperation for the protection of the marine environment.

27 OSPAR Commission, 'Quality Status Report 2010. Chapter 10: Protection and Conservation of Biodiversity and Ecosystems' 155 available at http://qsr2010.ospar.org/en/media/ chapter_pdf/QSR_Chı_EN.pdf; accessed 13 October 2016.

28 Ibid.

29 United Nations Convention on the Law of the Sea (Opened for signature on 10 December 1982, entered into force 16 November 1994) 1833 UNTS 3.

30 OSPAR Convention for the Protection of the marine Environment of the North-East Atlantic (Opened for signature 22 September 1992, entered into force 25 March 1998) 2354 UNTS 67 .

31 Article 2 OSPar.

32 Ibid. 
Pursuant to Article 2 of LOSC, the coastal State has sovereignty over its territorial sea. This implies that in this zone, it is the coastal State which has the competence to undertake activities in the field of MSP, if so desired. ${ }^{33}$ However, the sovereignty is exercised subject to LOSC and to other rules of international law. ${ }^{34}$ As an illustration, coastal states shall have due regard to the rights and duties of other States, specifically in relation to the rights of innocent passage, and shall respect existing agreements, traditional fishing rights and existing submarine cables of other States. ${ }^{35}$

In the exclusive economic zone, the coastal State has sovereign rights for the purpose of exploring and exploiting, conserving and managing the natural resources, whether living or non-living, and with regard to other activities for the economic exploitation and exploration of the zone, such as the production of energy from the water, currents and winds. ${ }^{36}$ The coastal State also has sovereign rights over the continental shelf for the purpose of exploring it and exploiting its natural resources. ${ }^{37}$ The rights that the coastal State enjoys in the exclusive economic zone and over the continental shelf may be relevant for marine spatial planning purposes.

For all three zones, Article 194(2) LOSC and Article 3 Convention on Biological Diversity ${ }^{38}$ emphasize the responsibility of States to ensure that activities within their jurisdiction or control do not cause damage to the environment of other states, despite the sovereign rights to exploit their own resources pursuant to their own environmental policies. ${ }^{39}$ In addition to the provisions related to various maritime zones laid down in Articles 2, 17, 56 and 77, the LOSC provides several instruments relevant for MSP, such as the designation of sea lanes; prescription of traffic separation schemes; consent on the delineation of the course for the laying of pipelines on the continental shelf; and the measures to protect and preserve rare or fragile ecosystems as well as the habitat of depleted, threatened or endangered species and other forms of marine life. ${ }^{40}$

33 P Drankier, 'Embedding Maritime Spatial Planning in National Legal Frameworks' (2012) 14(1) Journal of Environmental Policy and Planning 7-27, at p. 9.

34 Art 2(3) LosC.

35 Article 51 LOSC.

36 Article $56(2)$ Losc.

37 Article 77 Losc.

38 The Convention on Biological Diversity (adopted 22 May 1992, entered into force 29 December 1993) 1760 UNTS 79.

39 Drankier $2012(\mathrm{n} 33)$ at p. 13.

$40 \quad$ Ibid., at p. 9 . 
With regard to the need for regional cooperation, Article 197 LOSC requires States to cooperate on a global basis and, as appropriate, on a regional basis, directly or through competent international organizations, in formulating and elaborating international rules, standards and recommended practices and procedures consistent with this Convention, for the protection and preservation of the marine environment, taking into account characteristic regional features. A more explicit requirement for regional cooperation from a spatial point of view can be found in Article 123 LOSC, which says that "States bordering an enclosed or semi-enclosed sea should co-operate with each other in the exercise of their rights and in the performance of their duties" under Losc. To this end, they shall endeavour directly or through an appropriate regional organization, (a) to coordinate the management, conservation, exploration and exploitation of the living resources of the sea; (b) to coordinate the implementation of their rights and duties with respect to the protection and preservation of the marine environment; (c) to coordinate their scientific research policies and undertake where appropriate joint programmes of scientific research in the area; (d) to invite, as appropriate, other interested States or international organizations to cooperate with them in furtherance of the provisions of this article.

An example of the latter can be found in Article 3(9) of the Marine Strategy Framework Directive, which provides that 'regional cooperation' means “cooperation and coordination of activities between Member States and, when possible, third countries sharing the same marine region or sub-region, for the purpose of developing and implementing marine strategies". As will be shown below, the Directive on Maritime Spatial Planning has a similar provision.

In sum, coastal states surrounding an enclosed or semi-enclosed sea, such as the North Sea, should thus be influenced by the exhortation to cooperate in the manner in which they exercise their rights and duties under the LOsc. ${ }^{41}$ Such regional cooperation could be facilitated through the existence of regional organisations that provide a forum for knowledge sharing, collaboration and policy convergence.

\section{OSPAR}

The adoption of the OSPAR Convention facilitated an important change in the intensity of cooperation between the North Sea States on environmental matters. Whomersley describes the ospar Convention as "a sophisticated

41 C Whomersley, 'Regional Cooperation in the North Sea under Part IX of the Law of the Sea Convention' (2016) 31 The International Journal of Marine and Coastal Law 339-358, at p. 344 . 
instrument, including an important annex on the protection and conservation of the ecosystems and biological diversity of the maritime area". ${ }^{42}$ Various decisions and recommendations have been adopted over a wide range of issues. A detailed North-East Atlantic Environment Strategy has been adopted, which emphasises the importance of implementing an ecosystem approach to the environment and presents a number of thematic strategies. Reflecting the increasing concern amongst the coastal states about the health of the North Sea, a series of International Conferences on the Protection of the North Sea have also been held. ${ }^{43}$

Work under the OSPAR Convention is managed by the OSPAR Commission, made up of representatives of the Governments of 15 Contracting Parties and the European Commission, representing the European Union. The OSPAR Commission is, in accordance with Article 197 and 123 LOSC, the competent regional organisation guiding international cooperation on the protection of the marine environment of the North-East Atlantic. ${ }^{44}$

OSPAR has played a leading role in the development and application of ecosystem-based management within the region. The Bergen Declaration, made at the 5th North Sea Conference in 2002 established a conceptual framework for implementation of an ecosystem approach within the North Sea. ${ }^{45}$ This recognized the need to manage all human activities that affect the North Sea, in a way that conserves biological diversity and ensures sustainable development. The framework included the trialling of Ecological Quality Objectives (EcoQOs) and indicators to monitor the health of the North Sea ecosystem. ${ }^{46}$

The Bergen Declaration has also been highly important for the issue of MSP as it raised awareness for potential conflicts between the conservation of the marine environment and the cumulative effects of human activities. The representatives present at the 2002 North Sea Conference agreed that co-operation among states in the spatial planning processes of the North Sea was required. ${ }^{47}$ To that end, the OSPAR Commission was asked to improve arrangements for the exchange and experiences of national spatial planning

\footnotetext{
$42 \quad$ Ibid., at p. $35^{2}$.

43 Ibid., at p. 354 .

44 S Schmidt et al., Technical paper on the ecosystem based approach in marine and coastal policies (13 November 2015), at p. 29.

45 OSPAR, Ministerial Declaration of the Fifth International Conference on the Protection of the North Sea, 20-21 March 2002, Bergen, Norway, at http://www.ospar.org/html_documents/ ospar/html/bergen_declaration_final.pdf.

46 Schmidt et al. 2015 (n 44) at p. 30.

47 OSPAR 2002 (n 44) Section XI, para. 76.
} 
processes, to investigate the possibilities for further international cooperation in spatial planning and to consider the improvement of environmental assessment of human activities. ${ }^{48}$ For this purpose, the OSPAR Biodiversity Committee was invited

to investigate the possibilities for further international cooperation in planning and managing marine activities through spatial planning of the North Sea States taking into account cumulative and transboundary effects. ${ }^{49}$

In January 2004, at the first Workshop on Spatial Planning in the North Sea (SPINS 1), the OSPAR Secretariat presented a first attempt to review the existing spatial control mechanisms of the North Sea States. The review

showed that there was a wide range of spatial controls in all North Sea States covering most, if not all, relevant human activities. However, no North Sea State (except possibly Belgium) had clear arrangements to demonstrate that consistent approaches were being applied in the many different fields, though no doubt in practice there was much informal cooperation to ensure consistency. ${ }^{50}$

With regard to the MSP process, SPINS 1 concluded that:

[w]ithin the framework of international laws and obligations (including the LOSC), it is for each State to define its priorities for the use of the marine resources available to it. The main focus of spatial planning of the North Sea should therefore be at the national level. ${ }^{51}$

After two SPINS workshops with focus on the North Sea, three workshops on Marine Spatial Management (MASMA) followed in 2005, 2006 and 2007 extending their scope outside the North Sea. At MASMA 2006, the chairman concluded that the task of information collection and exchange should continue to be on the agenda for OSPAR work on marine spatial management and endorsed

\footnotetext{
48 Maes and Cliquet 2015 (n 10) at p. 86.

49 OSPAR 2002 (n 45) Section XI, para. 77(ii).

50 OSPARCom (2004) Workshop Report, sPins 2004, 04/5/1-E, Annex 1, para. 2.3.

51 OSPARCOM (2004) Workshop Report, SPINS 2004, 04/5/1-E, para. 6.
} 
the need for an overview of national spatial planning systems, recognizing the diversity of national systems. ${ }^{52}$

From the 2010s, MSP was considered important particularly for the implementation of an ecosystem-based approach in the North Sea and for the implementation of states' commitments under Eu legislation, such as the EU Marine Strategy Framework Directive. ${ }^{53}$ Indeed, in 2010, the OSPAR Commission published its Strategy for the Protection of the Marine Environment of the North-East Atlantic 2010-2020. ${ }^{54}$ The Strategy emphasizes the importance of the ecosystem approach and notes that the implementation of the ecosystem approach will take place within the framework of the obligations and commitments of the various Contracting Parties, individually or jointly, in this field, such as under the EU MSFD. ${ }^{55}$

The 2010 Bergen Statement, which mainly focused on the contribution by OSPAR to the implementation of the EU Marine Strategy Framework Directive to protect species and habitats, including Marine Protected Areas, within and beyond national jurisdiction, and to focus on various sources of pollution and adverse impacts of human activities, reaffirmed the ecosystem approach. The Bergen Statement considers MSP to be a tool to support the ecosystem approach. ${ }^{56}$

From a regional policy and legal perspective, Maes and Cliquet conclude that the EU, rather than OSPAR, has become the major player in stimulating transboundary MSP. They argue that:

OSPAR seems to have no strong ambition to play an active role in supporting cross-border cooperation on MSP between its members. Its contribution to MSP is mainly focused on collecting scientific data and the assessment of the impacts of human activities on the marine environment, as a contribution to the implementation of the EU MSFD by its Parties. $^{57}$

$52 \quad$ Maes and Cliquet 2015 (n 10) at p. 93.

53 Council Directive 2008/56/EC of 17 June 2008 establishing a framework for community action in the field of marine environmental policy [2008] OJ L 164/19.

54 OSPAR, The North-East Atlantic Environment Strategy of the OSPAR Commission for the Protection of the Marine Environment of the North-East Atlantic 2010-2020, http://www .ospar.org/site/assets/files/1413/10-03e_nea_environment_strategy.pdf.

55 Schmidt et al. 2015 ( $\mathrm{n} 44)$ at pp. 30-31.

56 OSPAR, 'Bergen Statement', Ministerial Meeting of the ospar Commission, Bergen 23-24 September 2010, paragraph 8, http://www.ospar.org/site/assets/files/1498/ospar_ 2010_bergen_statement.pdf. See Maes and Cliquet 2015 (n 10) at pp. 94, 95.

57 Maes and Cliquet 2015 (n 10) at p. 97. 
Drankier however argues that "[a]lthough there is no legal framework for MSP at the OSPAR level, cautious efforts are being undertaken to stimulate the debate on regional strategic MSP". 58 Strategic cooperation would involve "the joint setting of priorities on a spatial scale that encompasses the North Sea in its entirety and also takes into account what happens in and on neighbouring seas".59

As an illustration, the Secretariat of the OSPAR Commission presented an interesting proposal for a draft Recommendation on a MSP Consultation Procedure for consideration as work in progress at the Meeting of the OSPAR Commission, 20-24 September 2010. The draft Recommendation aims to establish a procedure where Contracting Parties inform, consult and where appropriate cooperate with each other at an early stage, with a view to amicably resolving any controversial issues concerning transboundary effects from the proposed maritime spatial plan. However, the Recommendation was not adopted due to reservations by Belgium, France and the UK. ${ }^{60}$

Despite the aim to improve strategic cooperation in the North Sea region, Drankier notices that the examples mentioned of possible joint strategic initiatives by OSPAR, ${ }^{61}$ all refer to sectoral issues such as joint planning of wind farm areas or nature protection areas or a shared view on the integration of fisheries in MSP. ${ }^{62}$ Flannery also notes that

[w[hile some cross-border consultation takes place, it is often ad hoc with little or no evidence of joint planning. Transitioning to transboundary MSP will be challenging. It will be difficult, for example, for neighbouring states to effectively cooperate on transboundary planning decisions without each state having explicit efforts on MSP. Furthermore, cooperation is impeded as neighbouring jurisdictions have different MSP timeframes, with some nations having considerably more developed MSP processes than others. ${ }^{63}$

Another complicating factor, identified by Hey (2002) is that the process of change is a long-term process, which implies that results cannot be expected

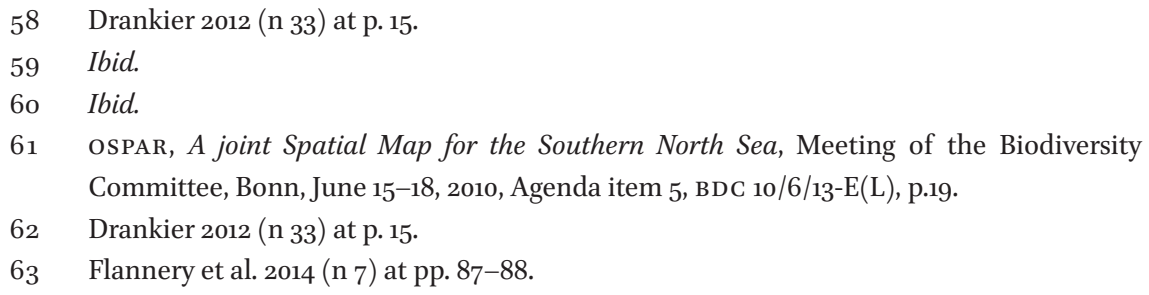


over a period of a few years. It is important to realise that the transition process is in fact about achieving changes in perception that are often deeply ingrained in society and may differ among societies. It is about changing our perceptions of the environment and its resources and of the role that science, technology and economic aspects can play in determining the manner in which we use the environment and its resources. ${ }^{64}$

Policy and legislative structures are often a reflection of these diverse national perceptions and circumstances. To what extent transboundary MSP would be realisable under these diverse legislative frameworks needs to be further assessed. Before providing an overview of national MSP related policies and laws in Norway and the Netherlands, the next section will first provide an overview of EU's legal framework for the protection of the North Sea. As providing a supranational legal framework, EU law might have important harmonizing potential. The most important EU Directives will be discussed, their relevance to Norway (as a non-EU Member State), as well as the role of OSPAR in the implementation of these Directives.

\section{EU Legal Framework for the Protection of the North Sea}

In addition to the LOSC and the OSPAR, a number of EU Directives are also of particular relevance to the governance of the North Sea ecosystem. These are in particular the EU Habitats Directive, ${ }^{65}$ the EU Birds Directive, ${ }^{66}$ the EU Marine Strategy Framework Directive, and the EU Directive on Maritime Spatial Planning. However, although none of these directives apply in Norway because it is not a member of the $\mathrm{EU}$, it is a member of the European Economic Area, based on the EEA Treaty with its Protocols and Annexes. ${ }^{67}$ Therefore, a large part of EU law is applicable to Norway through Article 7 of the EEA Treaty. With regard to environmental law however, only some of the directives

64 E Hey, 'The International Regime for the Protection of the North Sea: From Functional Approaches to a More Integrated Approach' (2002) 17(3) The International Journal of Marine and Coastal Law 325-350, at pp. 348-350.

65 Council Directive 92/43/EEC of 21 May 1992 on the Conservation of Natural Habitats and of Wild Fauna and Flora [1992] oJ L 206/7.

66 Council Directive 2009/147/EC of 30 November 2009 on the conservation of wild birds [2009] oj L 20/7.

67 Agreement on the European Economic Area between the European Community, its individual Member State and the EFTA member countries Austria, Finland, Iceland, Lichtenstein, Sweden and Norway of 2 May 1992. The Agreement was implemented in Norwegian law by Act of 27 November 1992 No 109. 
apply in Norway. The particular rules that Norway has to comply with have been listed in protocols and annexes; especially Annex Xx to the EEA Treaty. These include, for instance, rules relating to product control and pollution, the Water Framework Directive, and the directive concerning environmental impact assessments.

\section{The EU Habitats Directive and the EU Birds Directive}

The Habitats and Birds Directive apply within the territory of the EU Member States and form the cornerstone of Europe's nature conservation policy. The main aim of the Habitats Directive is to promote the maintenance of biodiversity by requiring Member States to take measures to maintain or restore natural habitats and wild species listed in the Annexes to the Directive at a favourable conservation status, introducing robust protection for those habitats and species of European importance. ${ }^{68}$ The Birds Directive provides a framework for the conservation and management of, and human interactions with, wild birds in Europe. It sets broad objectives for a wide range of activities, although the precise legal mechanisms for their achievement are at the discretion of each Member State.

The Habitats and Birds Directives are a means by which the European Union meets its obligations under the Bern Convention ${ }^{69}$ and Bonn Convention. ${ }^{70}$ The Bern Convention, which covers most of the natural heritage of the European continent, aims to conserve wild flora and fauna and their natural habitats and to promote European co-operation in that field. The Convention places a particular importance on the need to protect endangered natural habitats and endangered vulnerable species, including migratory species. ${ }^{71}$ The Bonn Convention aims to conserve terrestrial, marine and avian migratory species throughout their range. Parties acknowledge the importance of migratory species being conserved, and also of the need to take action to avoid any migratory species becoming endangered..$^{72}$ Though the Habitats and Birds Directives do not apply to Norway, both international conventions have been ratified by Norway.

\footnotetext{
68 The Habitats Directive (n 65) preamble.

69 The Convention on the Conservation of European Wildlife and Natural Habitats (opened for signature 19 September 1979 entered into force 1 June 1982) 1284 UNTS 209.

70 The Convention on the Conservation of Migratory Species of Wild Animals (opened for signature 23 June 1979, entered into force on 1 November 1983) 1651 UNTS 333 .

71 Article 1 Bern Convention (n 69).

72 Article 2 Bonn Convention (n 70 ).
} 
With regard to the issue of the geographical scope of the directives, it has become clear that the Directives also apply to waters under the Member State's jurisdiction and in waters where they exercise sovereign rights. The Directives thus apply to internal waters and the territorial sea, the exclusive economic zone, and the continental shelf. ${ }^{73}$ In the exclusive economic zone and continental shelf though, the coastal State only has certain sovereign rights and therefore the Directives only apply in the exclusive economic zone and continental shelf to the extent of the coastal State's rights.

Initially, a number of states reasoned that their obligations were restricted to the territorial waters. The European Commission has however consistently challenged this by arguing that the protection of marine habitats and species cannot be adequately ensured in such a limited area. After a number of years, the Council recognised the need for implementation of the Habitats and Birds Directives in the exclusive economic zone as a key element for the protection of the marine ecosystems. This opinion was also confirmed by the position of the European Court of Justice in its Judgment of 20 October 2005 (case C-6/04). ${ }^{74}$

The network of Special Protected Areas that has been established in accordance with the Birds Directive together with a community-wide network of Special Areas of Conservation established in accordance with the Habitats Directive constitutes a coherent European ecological network to be called 'Natura 200o'. The most important legal consequence of the designation of sites under the Habitat Directive and Birds Directive is that the condition or quality of these areas should not deteriorate. Plans and projects in these areas likely to have significant effect must undergo an appropriate assessment of its implications for the site in view of the site's conservation objectives. ${ }^{75}$ Impact assessments thus have to be carried out for any project that may have a significant effect on the site. ${ }^{76}$

As Norway has not implemented the Habitats and Birds Directives, no protected areas have been established in Norway pursuant to these Directives. Although a number of protected areas have now been established in

73 European Commission, 'Guidelines for the Establishment of the Natura 2000 Network in the Marine Environment. Application of the Habitats and Birds Directives' (May 2007) 18; Case C-6/04 Commission of the European Communities $v$ The United Kingdom of Great Britain and Northern Ireland [2005] ECR I-9017.

74 Ibid.

75 MA Heldeweg and RJGH Seerden, Environmental Law in the Netherlands (Kluwer, Dordrecht, 2012) at p. 171.

76 Article 6.3 of the Habitats Directive (n 65). 
accordance with other national legislation, ${ }^{77}$ these areas do not constitute part of the Natura 2000 network and are not subject to the strict rules of the Habitats and Birds Directives regulating human activities that potentially may adversely affect these areas.

\section{The Marine Strategy Framework Directive (MSFD)}

Besides the Habitats Directive and the Birds Directive, another important directive for the protection of the North Sea's ecological integrity is the Marine Strategy Framework Directive (MSFD) which was adopted in $2008 .^{78}$ The MSFD establishes a framework for the development of marine strategies designed to achieve 'Good Environmental Status' in the marine environment, by the year 2020, using 11 qualitative descriptors. Examples of these are elements of marine food webs, biological diversity, hydrographical conditions and sea floor integrity. 79 'Good environmental status' refers to marine waters which provide ecologically diverse and dynamic oceans and seas which are clean, healthy and productive within their intrinsic conditions. The use of the marine environment should be at a level that is sustainable, thus safeguarding the potential for uses and activities by current and future generations. ${ }^{80}$

The MSFD calls for the development of a marine strategy by each Member State. The purpose of these marine strategies is to protect and preserve the marine environment, prevent its deterioration or, where practicable, restore marine ecosystems in areas where they have been adversely affected. In addition, the strategies shall be developed and implemented in order to prevent and reduce inputs in the marine environment. ${ }^{81}$ Such a marine strategy includes an initial assessment of the current environmental status of national marine waters and the environmental impact and socio-economic analysis of human activities; the determination of what 'good environmental status' means for national marine waters; the establishment of environmental targets and associated indicators to achieve 'good environmental status' by 2020 ; the establishment of a monitoring program for the ongoing assessment and the regular

77 Three protected areas in Norway's coastal area have recently been designated pursuant to the Nature Diversity Act.

78 Council Directive 2008/56/EC of 17 June 2008 establishing a framework for community action in the field of marine environmental policy oJ L164/19.

See further Annex 1 to the Marine Strategy Framework Directive (n 78 ); see also European Commission, 'Relationship between the initial assessment of marine waters and criteria for good environmental status' (Working Paper) SEC (2011) 1255 final. This document distinguishes the descriptors further into criterion and indicators.

8o Article 3 (5) of the Marine Strategy Framework Directive ( $\mathrm{n} 78$ ).

81 Article 1.2 of the Marine Strategy Framework Directive (n 78 ). 
update of targets; and the development of a program of measures designed to achieve or maintain 'good environmental status' by $2020 .{ }^{82}$

The MSFD does not apply in Norway. However, the MSFD requires that Member States sharing a marine region or sub region, such as the North Sea ecosystem cooperate to ensure that the measures taken to achieve the objectives of the directive are coherent and coordinated across the marine region. ${ }^{83}$ The MSFD requires 'regional cooperation' which means cooperation and coordination of activities between Member States and, whenever possible, third countries sharing the same marine region or sub region, for the purpose of developing and implementing marine strategies. ${ }^{84}$ Article 6.2 stipulates:

For the purpose of establishing and implementing marine strategies, Member States shall, within each marine region or sub region, make every effort, using relevant international forums, including mechanisms and structures of Regional Sea Conventions, to coordinate their actions with third countries having sovereignty or jurisdiction over waters in the same marine region or sub region.

In this context, the OSPAR Commission drafted a Roadmap in $2010^{85}$ and published a report in 2012 entitled 'Finding common ground-Towards regional coherence in implementing the Marine Strategy Framework Directive in the North-East Atlantic region through the work of the OSPAR Commission: ${ }^{86}$ OSPAR Contracting Parties that are EU Member States have agreed that the OSPAR Commission should be the main platform through which they coordinate their work to implement the MSFD in the North-East Atlantic. The OSPAR Commission will facilitate the implementation of the MSFD by implementing its 2010 North-East Atlantic Environment Strategy and by contributing to the further development of the elements of good environmental status under the

82 Article 5.2 of the Marine Strategy Framework Directive (n 78).

83 Ibid.

84 Article 3.9 of the Marine Strategy Framework Directive (n 78 ).

85 OSPAR Commission, 'OSPAR Regional Implementation Framework for the EU Marine Strategy Framework Directive. MSFD Road Map' (2010), available at http://www .ospar.org/documents/dbase/publications/poo501/poo501_msfd\%2oroadmap.pdf; accessed 13 October 2016.

86 OSPAR Commission, 'Finding common ground-Towards regional coherence in implementing the Marine Strategy Framework Directive in the North-East Atlantic region through the work of the OSPAR Commission' (2012), available at http://www.ospar.org/ documents?v=7305; accessed 13 October 2016. 
MSFD, to the extent this is relevant for the respective strategies. ${ }^{87}$ Vice versa, the implementation of the MSFD will contribute towards OSPAR's objectives. ${ }^{88}$ The Strategy identifies a number of key steps it will apply in implementing the ecosystem approach:

(i) setting and coordinating ecological objectives and associated targets and indicators;

(ii) ongoing management; and

(iii) regular update of ecosystem knowledge, research and advice.

The Strategy notes that monitoring and assessment, as well as adaptive management, are essential elements for implementing the ecosystem approach and that adaptive management requires the application of the precautionary principle so that measures are taken when cause-effect relationships are not yet fully established scientifically, and modified when more knowledge becomes available. ${ }^{89}$ So far, collaboration with Norway has mainly consisted of the development of joint indicators for the monitoring of the state of the marine environment.90

Apart from the development of joint indicators, Schmidt et al. (2015) concluded that so far transboundary cooperation among OsPAR Contracting Parties to ensure alignment of definitions, protocols and standards for implementation of the ecosystem approach is very limited. As an illustration, Schmidt et al. mention that Member States have failed in applying a joint and coherent approach within regional seas in their initial assessments for the MSFD. More cooperation and coordination is recommended across national borders to ensure consistent ecosystem-based approaches based on ecological boundaries. $^{91}$

More specifically, lack of data and knowledge and the difficulty to integrate existing information due to different standards and formats has been identified as a major challenge for implementing a consistent ecosystem-based approach. In the Member States' reports on their initial assessments for the MSFD, particularly on the impacts of emerging pressures such as underwater noise or marine litter on ecosystems, a severe lack of data was identified. Knowledge on cumulative impacts caused by pressures from different sectors




and on environmental limits also remains scarce and difficult to obtain. These findings imply that an understanding of impacts of human activity on the marine environment, necessary to support the implementation of ecosystembased approaches, including spatial management decisions, is still limited. ${ }^{92}$

\section{The Maritime Spatial Planning Directive (MSPD)}

On 23 April 2014, the EU adopted the MSPD, establishing a framework for maritime spatial planning. ${ }^{93}$ The MSFD recognizes that " $[t]$ he high and rapidly increasing demand for maritime space for different purposes, such as installations for the production of energy from renewable sources, oil and gas exploration and exploitation, maritime shipping and fishing activities, ecosystem and biodiversity conservation, the extraction of raw materials, tourism, aquaculture installations and underwater cultural heritage, as well as the multiple pressures on coastal resources, require an integrated planning and management approach". ${ }^{94}$ Marine spatial planning will contribute to the effective management of marine activities and the sustainable use of marine and coastal resources, by creating a framework for consistent, transparent, sustainable and evidence-based decision-making. In order to achieve its objectives, the MSPD lays down obligations to establish a maritime planning process, resulting in a marine spatial plan or plans; such a planning process should take into account land-sea interactions and promote cooperation among Member States. ${ }^{95}$

An important aim of the MSPD is also to reduce the administrative burden and costs in support of their action to implement other relevant European Union legislation. The timelines for maritime spatial plans should therefore, where possible, be compatible with the timetables set out in other relevant legislation, including the MSFD, which requires Member States to take the necessary measures to achieve or maintain good environmental status in the marine environment by 2020 and identifies maritime spatial planning as a tool to support the ecosystem-based approach to the management of human activities in order to achieve good environmental status. ${ }^{96}$

Similar to the MSFD, the MSPD also requires cooperation with third countries. Article 12 requires that

\footnotetext{
$92 \quad$ Ibid., at p. 47.

93 Council Directive 2014/89/EU of 23 July 2014 establishing a framework for maritime spatial planning OJ L257/135.

94 Ibid., Preamble (1).

95 Ibid., Preamble (9).

$96 \quad$ Ibid., Preamble (22).
} 
Member States shall endeavour, where possible, to cooperate with third countries in their actions with regard to maritime spatial planning in the relevant marine regions and in accordance with international law and conventions, such as by using existing international fora or regional institutional cooperation.

Through this provision, Norway may become involved in spatial planning strategies in the North Sea ecosystem. So far, perhaps because the Directive is relatively recent, negotiations with Norway in the context of this Directive have not yet taken place. ${ }^{97}$

The Road towards the MSPD

The MSPD was preceded by a number of regulations and strategies that eventually led to its adoption. In 2011, an EU Regulation was adopted, establishing an EU program to further promote the development and the implementation of EU's integrated maritime policy (IMP). ${ }^{98}$ The Regulation states that "[ $\left.\mathrm{t}\right] \mathrm{his}$ program shall, amongst others, support the protection and preservation of the marine and coastal environment, and contribute to the health, biological diversity and resilience of marine and coastal ecosystems".99 Article 1 of the Regulation stipulates that EU's IMP

shall foster coordinated and coherent decision-making to maximize the sustainable development, economic growth and social cohesion of Member States, in particular with regard to coastal, insular and outermost regions in the Union, as well as maritime sectors, through coherent maritime-related policies and relevant international cooperation. ${ }^{100}$

Article 3 of the Regulation further states that:

The program established by the Regulation shall foster the development of Maritime Spatial Planning and Integrated Coastal Zone Management, which are both important tools for the sustainable development of

97 Personal communication, 19.12.2016.

98 Council Regulation 1255/2011 of 5 November 2011 establishing a Programme to support the further development of an Integrated Maritime Policy, oJ L 321/1.

99 Ibid., Article 3(a) and 3(b).

100 Ibid., Article 1. 
marine areas and coastal regions and both contributing to the aims of ecosystem-based management $[\ldots ..] .^{101}$

Both MSP and Integrated Coastal Zone Management are thus important aspects of the Regulation, as well as of the future MSPD. Both tools are planning frameworks for public authorities and stakeholders to coordinate their actions to optimize the use of marine space under the sovereignty and jurisdiction of the Member States.

MSP has thus been identified as a cross-sectoral tool that can support the implementation of the IMP. ${ }^{102}$ The European Commission described MSP as "an integrated and balanced tool that has the potential to provide long-term stability and predictability, as well as to manage competition for space in intensively used areas". ${ }^{103}$ Such a tool is crucial for all economic sectors such as maritime transport, oil and gas, sand and gravel, renewable energy, fisheries, aquaculture, tourism and for the protection of the environment. ${ }^{104}$ In the Roadmap for Maritime Spatial Planning, which the Commission adopted in 2008 , the ecosystem approach was highlighted as an overarching principle for MSP. ${ }^{105}$

The European Commission emphasises that even though a great deal of MSP can be achieved at the national level, the Commission considers it important to pursue action at EU level to achieve a coherent framework for MSP within the EU. A common approach would enable efficient and smooth application of MSP in transboundary marine areas, favouring the development of maritime activities and the protection of the marine environment based on a common framework and similar legislative implications. MSP is also crucial for legal certainty, predictability and transparency, thus reducing costs for investors and operators, in particular those operating in more than one Member State. ${ }^{106}$

\footnotetext{
101 Ibid., Article 3.

102 European Commission, 'An Integrated Maritime Policy for the European Union' (Blue Paper) сом (2007) 574 final; European Commission, 'Action Plan on an EU Integrated Maritime Policy' Сом (2007) 575 final.

103 European Commission, 'Maritime Spatial Planning in the EU-Achievements and future development' сом (2010) 771, 2.

104 Ibid.

105 European Commission, 'Roadmap for Maritime Spatial Planning: Achieving Common principles in the EU' сом (2008) 791 final.

106 ospar, 'Bergen Statement', Ministerial Meeting of the ospar Commission, Bergen 23-24 September 2010, 1, http://www.ospar.org/site/assets/files/1498/ospar_2010_bergen_ statement.pdf.
} 
The 2008 Roadmap for Maritime Spatial Planning includes 'cross-border cooperation and consultation' as one of its guiding principles: cooperation across borders is necessary to ensure the coherence of plans across ecosystems. ${ }^{107}$ Furthermore, according to the 2010 Communication on Achievements and Future Development, consultation and cooperation with neighbouring States needs to take place at an early stage and the development of a joint vision should be based on exploration of common interests. ${ }^{108}$ In the European seas, due to the proximity of adjacent or opposite states and the jurisdictional fragmentation of the marine space thereof, it soon became evident that small-scale MsP projects confined the effectiveness of MSP processes. ${ }^{109}$ The European Commission anticipated a homogenizing effect across Member States, through the formulation of ten MSP principles of the 2008 Roadmap. However, this homogenized effect was not realized. According to the 2010 Communication, Member States had followed diverse approaches, while in other cases no significant progress had been achieved.

Taking into account the fragmented legal and institutional landscape in the EU Member States, as well as the intensification and diversification of human activities at sea, the European Commission therefore decided to launch a legislative initiative in this domain ${ }^{110}$ to give transboundary cooperation in the context of MSP a firm legal footing. ${ }^{111}$

The proposed MSPD was published in March 2013. The proposed legislative act became a highly contentious issue among EU institutions and Member States. ${ }^{112}$ The proposed MSPD raised significant concerns due to the promotion of transboundary cooperation. The idea of pursuing coordination with other Member States, as well as bordering non-EU Member States, was not appreciated by most national authorities. Zervaki (2015) recognizes two main reasons for this hesitancy. Firstly, the multiplicity of established legal, institutional and administrative mechanisms makes cooperation more difficult, especially when the unifying effect of $\mathrm{E} U$ legislation is missing in relation to third countries. Secondly, the fact that there are still many pending disputes and

107 European Commission, 'Roadmap for Maritime Spatial Planning: Achieving Common principles in the EU' сом (2008) 791 final, seventh principle.

108 Drankier 2012 (n 33) at p. 8.

109 A Zervaki, 'Introducing Maritime Spatial Planning legislation in the EU: Fishing in Troubled Waters?' (2015) 1 Maritime Safety and Security Law Journal 95-114, at 98.

110 Ibid., at p. 104.

111 AJ Gilbert et al., 'Marine spatial planning and Good Environmental Status: a perspective on spatial and temporal dimensions' (2015) 20 (1) Ecology and Society 64.

112 Zervaki 2015 (n 109) at p. 104. 
claims being raised among Member States and between Member States and non-EU Member States is a parameter that should not be neglected, since the MSP process needs clearly defined maritime jurisdiction of the coastal states. ${ }^{113}$ For these reasons, the legal requirements of the MSPD are mainly of a procedural nature.

\section{Procedural Legal Requirements}

An important requirement pursuant to Article 5 MSFD is that Member States develop maritime spatial plans which should be comprehensive. Through these, Member States shall "aim to contribute to the sustainable development of energy sectors at sea, of maritime transport, and of the fisheries and aquaculture sectors, and to the preservation, protection and improvement of the environment, including resilience to climate change impacts. Other objectives may also be pursued, such as the promotion of sustainable tourism and the sustainable extraction of raw materials".14 The Member States themselves determine how the different objectives are reflected and weighted in their maritime spatial plan or plans. ${ }^{115}$

The MSPD contains a number of minimum requirements related to the maritime spatial plans. Pursuant to Article 6, Member States shall for instance ensure the involvement of stakeholders; organize the use of the best available data, ensure transboundary cooperation between Member States; and promote cooperation with third countries. In light of the need for transboundary cooperation and coordination between the North Sea surrounding states, the requirement for cooperation among Member States and with third countries is especially interesting. ${ }^{116}$

Cooperation among Member States should be part of the planning and management process. Member States bordering the North Sea "shall cooperate with the aim of ensuring that maritime spatial plans are coherent and coordinated across the marine region concerned. Such cooperation shall take into account, in particular, issues of a transnational nature".17 In addition to the cooperation among Member States, there needs to be cooperation with nonEU Member States such as Norway. Article 12 stipulates that

\footnotetext{
113 Ibid., at p. 105.

114 Article 5(2), MsP Directive.

115 Article 5(3), MSP Directive.

116 Articles 11 and 12, MSP Directive.

117 Article 11(1) MSP Directive.
} 
Member States shall endeavour, where possible, to cooperate with third countries on their actions with regard to maritime spatial planning in the relevant marine regions and in accordance with international law and conventions, such as by using existing international forums or regional institutional cooperation. ${ }^{118}$

In short, pursuant to the MSP Directive, Member States are thus asked to draw up maritime spatial plans that will map existing human activities, as well as displaying their future spatial developments at sea. Member States then need to develop integrated coastal management strategies which will ensure coordinated management of these human activities in coastal areas. They will have to fulfil minimum requirements which are of procedural nature: develop maritime spatial plans and integrated coastal management strategies, and establish appropriate transboundary cooperation among them. The MSPD respects Member States prerogatives to tailor the content of the plans and strategies to their specific economic, social and environmental priorities, as well as their national sectoral policy objectives and legal traditions. The planning details and determination of management objectives are left to Member States. ${ }^{119}$

Although the responsibility for MSP lies at the national level and addresses maritime activities in a nation's exclusive economic zone, a transboundary, sub regional and even a regional sea perspective is required when maritime activities and/or their effects cross national borders. ${ }^{120}$ Zervaki (2015) is critical with regard to the potential of the MSPD to establish such transboundary cooperation arguing that " $[t]$ he framework for interstate cooperation is however not clear, the Directive does not create new coordinating bodies or structures for that purpose: it instead delegates the coordination of regional cooperation mainly to the existing regional sea conventions." However, the role of these regional institutions is not explicitly defined. Zervaki suggests that "this may not be a problem in the Northern marine areas where regional cooperation in MSP

118 Zervaki argues that this MSPD philosophy of 'enhanced' cross border cooperation is in line with the LOSC provisions on bilateral, regional and international cooperation (art. 118 on the cooperation of states in the conservation and management of living resources, art 123 on the cooperation of states bordering enclosed or semi-enclosed seas, art 129 on the cooperation in the construction and improvement of means of transport, art 197 on cooperation on a global and regional level); see further Zervaki 2015 (n 109) at p. 112.

119 European Parliament, 'European Parliament legislative resolution of 17 April 2014 on the proposal for a directive of the European Parliament and of the Council establishing a framework for maritime spatial planning and integrated coastal maritime spatial planning and integrated coastal management' сом (2013) 0133 .

Gilbert et al. 2015 (n 111) at p. 64. 
is more advanced, but it may prove counterproductive in the Mediterranean or the Black Sea regions where institutional coherence among coastal states is comparatively low". ${ }^{121}$ In the North Sea though, an important challenge consists of actively including Norway in the development of transboundary cooperation initiatives, particularly when OSPAR seems to have no strong ambition to play an active role in supporting transboundary cooperation on MSP between its members. ${ }^{122}$

\section{Commentary}

The above overview demonstrates that coordinated governance of the North Sea ecosystem is complicated by the fact that many of the EU environmental directives do not apply to Norway. Even though these Directives encourage cooperation and coordination between Member States and non-EU member states like Norway, compliance with their requirements, measures and obligations is not necessary. Complying with the requirements and obligations of the MSFD would theoretically enable Member States to achieve 'good environmental status' of their marine environment and contribute to the maintenance of ecosystem integrity. Maintaining the integrity of the North Sea ecosystem 'as a whole' becomes more uncertain when the various countries that share the North Sea ecosystem do not implement and comply with a common legal framework.

Even among the Member States, achieving a more ecosystem-based governance approach to the North Sea ecosystem is not assured. Marine spatial planning as required by the MSPD could be an important tool for attaining a more ecosystem-based governance approach to the North Sea ecosystem. The procedural requirements of the Directive are minimal and Member States are allowed to tailor their plans and strategies to their specific economic, social and environmental priorities, as well as their national sectoral policy objectives and legal traditions. As a consequence, marine spatial planning in the North Sea among Member States can be complicated by their different policy and legal structures and traditions.

Most coastal states have developed their own set of policies, laws and regulatory instruments governing the use of their seas, which are often sectoral-based

121 Zervaki 2015 (n 109) at p. 111.

122 Maes and Cliquet 2015 (n 10) at p. 97. 
and complex. ${ }^{123}$ Transboundary marine spatial planning, interfacing with these frameworks operating at different levels, requires a very a good understanding of the regulatory frameworks and the administrative structures and responsibilities in question, at international, national and sub-national levels. ${ }^{124}$ The challenge is also that there may be different policy and planning practices and different maritime priorities, leading to individual MSP processes which are far from compatible in terms of timing and objectives. There may also be procedural obstacles for authorities seeking to work together in a transboundary manner, including unevenly matched administrative structures and processes, technical difficulties of sharing information, language barriers and other impediments to good communication. ${ }^{125}$

The following part of the article provides an overview of the policies and legal structures of Norway and the Netherlands as an illustration of the divergence that may exist among countries sharing a marine region.

\section{The Compatibility of National Policies and Legal Structures: A Comparison between Norway and the Netherlands}

MSP was designed to replace the current fragmented system of sectoral decision-making with a coordinated and coherent system of allocating space to marine users. ${ }^{126}$ In the transboundary perspective, this might be challenging as it requires a degree of harmonisation across jurisdictions and coherent policy and licensing arrangements for marine developments across borders. ${ }^{127}$ Schaefer and Barale (2011) thus argue that a common approach to managing marine space on each side of the border would enable efficient and smooth application of MSP, favouring the development of maritime activities and the protection of the marine environment based on a common framework and

123 SJ Boyes and M Elliot, 'The excessive complexity of national marine governance systems: has this decreased in England since the introduction of the Marine and Coastal Access Act 2009?' (2015) 51 Marine Policy 57-65.

124 S Jay et al., 'Transboundary dimensions of marine spatial planning: Fostering inter-jurisdictional relations and governance' (2016) 65 Marine Policy 85-96, at p. 93.

125 Ibid., at p. 86.

126 J Brennan et al., 'EU marine strategy framework directive (MSFD) and marine spatial planning (MSP): Which is the more dominant and practicable contributor to maritime policy in the UK?' (2014) 43 Marine Policy 359-366, at p. 362.

127 Jay et al. 2016 (n 124) at p. 89. 
similar legislative implications. ${ }^{128}$ Operationalizing MSP in transboundary areas based on a common legal framework and similar legislative implications sounds ideal, but not straightforward when common legal frameworks are lacking.

The following sections provide an overview of MSP related policies and laws in Norway and the Netherlands.

\section{National Policies for the North Sea in Norway}

In Norway, governance of the North Sea has been influenced by a number of policy documents, most importantly the White Paper 'Rent og Rikt Hav' of $2002,{ }^{129}$ and the Management Plan for the North Sea and Skagerrak of 2013.130

The first document, Rent og Rikt Hav, strongly emphasises the need for an ecosystem approach. The White Paper stresses that the North Sea is one of the most productive seas and that it is important to develop governance strategies that approach the ecosystem as a whole. The White Paper recognises that it is not possible or appropriate to expect that all sectors and users will have a complete overview over how their activities affect other sectors and activities in the ecosystem. The government is tasked with ensuring that activities and interventions in the coastal and marine environment are in accordance with a comprehensive plan, where interventions and impacts are assessed together. ${ }^{131}$ The government states that coordination between the different authorities needs to be strengthened if the objective of clean and rich sea areas is to be achieved. They therefore encourage a comprehensive governance approach of coastal and marine areas based on an ecosystem approach. ${ }^{132}$ The ecosystem approach is necessary in order to ensure that the cumulative environmental effects do not outweigh the maintenance of ecosystem structure, functioning and biodiversity on the long term. ${ }^{133}$

128 N Schaefer and V Barale, 'Marine spatial planning: opportunities \& challenges in the framework of the EU integrated maritime policy' (2011) 15Journal of Coastal Conservation 237-245, at p. 244.

129 Stortingsmelding nr. 12 [Storting White Paper nr. 12] (2001-2002) Rent og Rikt Hav [Protecting the Riches of the Seas].

130 Stortingsmelding nr. 37 [Storting White Paper nr. 37] (2012-2013) Helhetlig forvaltning av det marine miljø i Nordsjøen og Skagerrak (forvaltningsplan) [Integrated Management of the Marine Environment in the North Sea and Skagerak (Management Plan)].

131 Protecting the Riches of the Seas (n 129) paras. 2.1.3 and 2.2.1.

132 Ibid., para. 2.2.3.

133 Ibid. 
The establishment of management plans for the three seas that Norway borders: the Barents Sea, the Norwegian Sea and the North Sea is one way that Norway has moved forward with an ecosystem approach. The Management Plan for the North Sea that was finalized in 2013 is the most recent. The Management Plan for the Barents Sea and Lofoten area was released in 2006, ${ }^{134}$ and the Management Plan for the Norwegian Sea in 2009. ${ }^{135}$ These management plans have been approved by the Norwegian Parliament and have the status of non-legally binding 'white papers'. Importantly, these management plans represent inter-sectoral agreement on the governance of the particular marine areas. The Management Plan of the North Sea is intended to provide an overall framework for both existing and new activities in these areas and to facilitate the coexistence of industries and activities that affect the marine environment. The overall purpose of the plan is to

facilitate wealth creation through the sustainable use of natural resources and ecosystem services in the North Sea and the Skagerrak and simultaneously to maintain ecosystems' structure, functioning, productivity and biological diversity. ${ }^{136}$

In the Management Plan, the Government laid down a number of objectives for the governance of the North Sea and the Skagerrak areas under Norwegian jurisdiction. These objectives reflected relevant national and international aims for the environment. In addition, they supported the objective of the Management Plan and provided clear direction to any work on the improvement of the environmental status of the North Sea and the Skagerrak. Objectives in the Management Plan apply to all activities within its area. For the environment and the ecosystem in the North Sea and Skagerrak, the Government laid out the following objectives for ecosystem status and sustainable use (present-2020):

134 See Stortingsmelding nr. 8 [Storting White Paper nr. 8] (2005-2006) Helhetlig forvaltning av det marine miljø $i$ Barentshavet og havområdene utenfor Lofoten (forvaltningsplan) [Integrated Management of the Marine Environment of the Barents Sea and the Sea Areas off the Lofoten Islands (Management Plan)].

135 Stortingsmelding $\mathrm{nr} .37$ [Storting White paper nr. 37] (2008-2009) Helhetlig forvaltning av det marine miljø i Norskehavet (forvaltningsplan) [Integrated Management of the Marine Environment of the Norwegian Sea (Management plan)].

136 Management Plan for the North Sea (n 130) at p. 123. 
1. The marine environment in the North Sea and Skagerrak shall be governed in a manner in which the diversity of ecosystems, nature types, species and genes, are being conserved, and in which the ecosystem's productivity is maintained and improved. Human activity shall not harm ecosystems' functioning, structure, productivity or nature diversity.

2. Governance shall take due consideration to the need to conserve and protect vulnerable nature types and species within particularly valuable and vulnerable areas. Human activities shall exercise due caution and be conducted in a manner that does not threaten the ecological functions, productivity or nature diversity.

3. Naturally occurring species shall exist in viable populations that ensure reproduction and long-term survival. Species which are important for the ecosystem's functioning, structure and productivity shall be governed so that they can fulfil their role as key species in the ecosystem. Threatened and vulnerable species and nationally important species shall be maintained or restored to viable levels. The establishment of marine protected areas in the Norwegian coast and marine environmental shall contribute to an internationally representative network of marine protected areas.

4. Living marine resources shall be governed in a sustainable manner through an ecosystem-based approach, and based on the best available knowledge. Harvesting shall not have significant negative effects on other parts of the marine ecosystem or the ecosystem's structure. Bycatch of marine mammals and seabirds should be reduced to the lowest possible level. The harvesting of living marine resources shall be conducted with the best available techniques to minimize the adverse effects on other parts of the ecosystem, such as on marine mammals, seabirds and the sea floor.

5. The anthropogenic introduction and spread of organisms that do not occur naturally in ecosystems should be avoided. ${ }^{137}$

The Management Plan could be considered as an important tool to ensure that the marine environment contributes to long-term prosperity. The Management Plan also contributes to increasing predictability with regard to allocating space to different users and to strengthening the coordination

137 Management Plan for the North Sea (n 130) at pp. 123-124. 
between sectors that use the marine environment and exploit the natural resources in these areas. ${ }^{138}$

\section{Environmental Law in Norway}

Though the Management Plan for the North Sea attempts to implement an integrated governance approach for the Norwegian part of the North Sea, environmental law in Norway is still very fragmented. Environmental governance and law is influenced by the Environmental Policy Integration (EPI) principle. The EPI principle refers to the integration of environmental objectives and considerations into sector policy-making and planning (e.g. energy, transport, agriculture, and urban development) and is considered to be a key principle for realising sustainable development. ${ }^{139}$

Environmental law applicable to the Norwegian part of the North Sea mainly consists of a number of general laws which apply to terrestrial territory and out to 1 nautical mile from the baseline; a large number of sector laws; and the cross-sectoral 2009 Nature Diversity Act. For spatial planning, the most general legal act on land use is the 2008 Planning and Building Act (PBA). ${ }^{140}$ The PBA aims to "promote sustainable development in the best interest of individuals, society and future generations". ${ }^{141}$ The PBA mainly consists of two parts: rules with regard to land use planning and rules with regard to building and construction activities. Rules concerning land use planning aim at overall assessments of possible land uses within larger areas. The rules concerning building activities mainly aim to ensure that projects are in compliance with the land use plan in question and other applicable rules. In addition, the PBA contains rules with regard to environmental impact assessments, for land use plans as well as for plans and projects in accordance with other legal acts. ${ }^{142}$ The regional and land-use planning pursuant to the $\mathrm{PBA}$ is part of the responsibilities of the Ministry of Local Government and Modernisation. The intention of the PBA has been to develop close links between spatial planning and the management and conservation of biodiversity and other natural resources, conservation of cultural heritage, and pollution abatement.

\footnotetext{
138 Ibid., at p. 127.

139 European Environment Agency, Environmental policy integration in Europe. State of play and an evaluation framework (26 May 2005) Technical Report No. 2-2005, at p. 12.

140 Act of 27 June 2008 No. 71 relating to Planning and Building Applications.

141 Ibid, Article 1-1.

142 IL Backer, Innføring i naturressurs og miljørett (5th edn, Gyldendal akademisk, Oslo, 2012) at p. 170 .
} 
Therefore, the PвA contains several rules on the 'building permit system.'143 Besides establishing the system for comprehensive regional and land-use planning as well as building permissions, the PBA has certain rules that deal directly with the protection of the environment. The most important is the 'general prohibition to build less than 100 meters from the sea.' 144 In this zone, the PBA gives special consideration to the natural and cultural environment, outdoor recreation, landscape and other public interests. The general rule is that all types of construction and buildings, including enclosures, are prohibited in this zone. However, there are exceptions to this rule. ${ }^{145}$ Pursuant to Article 1.2, the Act applies to the whole land territory, including watercourses and the underground. It also applies to coastal waters inside of 1 nautical mile from the baseline. The government may decide whether Chapter 14 on 'environmental impact assessments' of projects shall apply to specific projects outside one nautical mile from the baseline. ${ }^{146}$ The P BA does not apply to marine pipelines for the transport of petroleum. ${ }^{147}$ Pipelines in the sea for the transport of petroleum are regulated by the Petroleum Act. Because the PBA only applies to the first nautical mile from the baseline, spatial planning within the territorial sea and the exclusive economic zone outside of 1 nautical mile is not regulated by any specific legal act in Norway.

Spatial planning of human activities in the North Sea are generally subject to permits, which are granted on the conditions specified in sectoral legislation. For example, the Marine Resources Act ${ }^{148}$ of 2008 regulates how, where, when and how much can be harvested of living marine resources. It provides a broad basis for the exploitation and management of living marine resources and lays down objectives and principles for the harvesting and other exploitation of all wild living resources in the sea, including fish, marine mammals, and other marine organisms and plants in the sea water as well as on the bottom, and including their genetic material. It also provides the Norwegian authorities with the necessary authority to regulate in detail the exploitation of wild living marine resources. ${ }^{149}$

\footnotetext{
143 HC Bugge, Environmental Law in Norway (2nd edn, Kluwer Law International, Alphen aan de Rijn, 2014) at p. 287.

144 Article $1-8$ of the Planning and Building Act.

145 Bugge 2014 (n 143) at p. 288.

146 Articles 1-2 of the Planning and Building Act.

147 Articles $1-3$ of the Planning and Building Act.

148 Act of 6 June 2008 No. 37 on the management of wild living marine resources.

149 Bugge 2014 (n 143) at p. 229.
} 
A major use of the marine environment in Norway is aquaculture. Over the last couple of decades, aquaculture or fish farming has become a major industry in Norway. Fish farming can pose serious environmental threats which make it necessary to regulate it. ${ }^{150}$ The Aquaculture Act ${ }^{151}$ of 2005 is an instrument that shall facilitate the industry players' creation of value, through profitable operations, in a socio-economically optimal manner. The purpose of the Aquaculture Act is "to promote the profitability and competitiveness of the aquaculture industry within the framework of sustainable development and contribute to the creation of value on the coast". 152 Under the Aquaculture Act, aquaculture is prohibited without a licence from public authorities (Article 4).

Another major activity in the Norwegian marine environment is petroleum exploitation. The 1996 Petroleum Act ${ }^{153}$ provides the general legal basis for the licensing system governing Norwegian petroleum activities. According to the Petroleum Act and its regulations, ${ }^{154}$ licences can be awarded for the exploration, production, and transport of petroleum. Official approvals and permits are necessary in all phases of petroleum activities, from award of exploration and production licences for acquiring seismic data and conducing exploratory drilling, to plans for development, operation, and field cessation. ${ }^{155}$

Most sector laws contain provisions stipulating that environmental considerations must be taken into account when making decisions for permitting. For example, the 2010 Offshore Energy Act ${ }^{156}$ which provides the legal framework for issuing licences and otherwise regulating conditions related to planning, constructing, operating and removing facilities for producing renewable energy and for transforming and transmitting electricity at sea, ${ }^{157}$ requires the authorities granting licences to consider whether actions need to be taken to avoid or minimise damages to nature, biological diversity, cultural heritage,

\footnotetext{
$150 \quad$ Ibid., at p. 234.

151 Act of 17 June 2005 No. 79 relating to aquaculture.

$15^{2}$ Article 1 of the Aquaculture Act.

153 Act of 29 November 1996 No. 72 relating to petroleum activities.

154 Regulations of 27 June 1997 No. 653 relating to refunding of expenses in connection with regulatory supervision of safety, working environment and resource management in the petroleum activities.

155 Norwegian Ministry of Petroleum and Energy and the Norwegian Petroleum Directorate, Facts 2012. The Norwegian Petroleum Sector (March 2012) at p. 14.

156 Act of 4 June 2010 No. 21 relating to offshore renewable energy production.

157 Norwegian Ministry of Petroleum and Energy, 'Concerning an Act on Offshore Renewable Energy Production (The Offshore Energy Act). Summary in English: Proposition No. 107 (2008-2009) to the Storting', at p. 3.
} 
or other uses of the area. ${ }^{158}$ Also the more general Pollution Control Act ${ }^{159}$ of 1981, which aims to prevent pollution and to protect the environment - mainly from stationary sources, stipulates that " $[\mathrm{w}]$ hen the pollution control authority decides whether a permit is to be granted and lays down conditions pursuant to section 16 , it shall pay particular attention to any pollution-related nuisance arising from the project as compared with any other advantages and disadvantages so arising". 160 These disadvantages encompass also environmental aspects.

Although many sector laws have provisions that require environmental considerations to be taken into account when making decisions or plans, the major legislation for nature protection in Norway is the Nature Diversity Act of 2009 (NDA). ${ }^{161}$ The NDA aims to "protect biological, geological and landscape diversity and ecological processes through conservation and sustainable use, and in such a way that the environment provides a basis for human activity, culture, health and well-being, now or in the future, including a basis for Sami culture". ${ }^{162}$ The NDA establishes a framework for protected areas. More specifically, the NDA sets the purposes of protected areas in general and identifies the individual categories of protected areas, in addition to a number of rules on permitted and prohibited actions. ${ }^{163}$ In June 2016, three marine protected areas have been established in the coastal areas of Norway pursuant to the NDA.

The NDA applies fully to nature on Norwegian land territory, including rivers systems, and in Norwegian territorial waters. Outside of territorial waters, on the continental shelf and in Norway's 200 nautical miles exclusive economic zone, only a few of the articles apply. These articles are in particular the provisions setting out the purposes and management objectives of the NDA and most of the principles for public decision-making including the precautionary principle and the ecosystem approach and cumulative effects. ${ }^{164}$

\footnotetext{
$15^{8}$ Articles 3-4 of the Offshore Energy Act.

159 Act of 13 March 1981 No. 6 concerning protection against pollution and concerning waste [Pollution Control Act].

16o Article 11 Pollution Control Act.

161 Act of 19 June 2009 no. 100 relating to the Management of Biological, Geological and Landscape Diversity [Nature Diversity Act].

162 Article 1 of the Nature Diversity Act.

163 OK Fauchald and LH Gulbrandsen, 'The Norwegian reform of protected areas management: A grand experiment with delegation of authority?' (2012) 17(2) Local Environment 203-222, at p. 207.

164 Article 2, third paragraph, states that the Articles 1, 3 to 5,7 to 10,14 to 16,57 and 58 apply on the continental shelf and the economic zone of Norway to the extent they are appropriate.
} 
In practice, this means that when decision-making authorities are making decisions on things like the issuing of a permit pursuant to a sector law, the decision-making principles of the NDA have to be taken into consideration. The NDA is namely a cross-sectoral act. The management objectives of the NDA as well as the principles for decision-making apply to the protection of biodiversity in pursuance of the NDA as well as to the authorisation of human activities and interventions in nature under other acts, such as the PBA or the Aquaculture Act. These NDA principles thus affect the exercise of discretionary powers and "shall serve as guidelines for the exercise of public authority" within the different sectors. ${ }^{165}$

As mentioned above, the cross-sectoral NDA does not apply to the entire area under Norwegian jurisdiction. As a result, outside of the territorial zone, environmental considerations are often weighed and integrated in accordance with the assessment frameworks laid down by sectoral legislation, though the environmental decision-making principles of the NDA have to be taken into account. The manner in which the different sectors integrate environmental considerations in their governance approaches can differ by context. Finding the appropriate balance between certain human activities and the protection of the environment, particularly outside of the territorial zone, appears not to be subject to an overall spatial planning perspective in which certain important ecological areas are (strictly) protected from human impacts. Though certain areas in the Norwegian part of the North Sea have been designated in the Integrated Management Plan for the North Sea as particularly 'vulnerable' or 'valuable', this does not necessarily result in any major consequences for the spatial planning of human activities, because the legislation applicable provides sector authorities with considerable room for discretion to weigh and balance different interests and considerations when making specific planning decisions. ${ }^{166}$

\section{National Policies for the North Sea in the Netherlands}

In the Netherlands, governance of the North Sea has been mainly described within three policy documents: The 2016-2021 National Water Plan, ${ }^{167}$ the

\footnotetext{
165 Article 7 of the NDA.

166 FM Platjouw, 'An illustration of the problem: offshore petroleum exploitation in the North Sea ecosystem' in FM Platjouw, Environmental Law and the Ecosystem ApproachMaintaining ecological integrity through consistency in law (Routledge, Abingdon, 2016) 143-183.

167 The Ministry of Infrastructure and the Environment and the Ministry of Economic Affairs, National Water Plan (December 2015), https://www.government.nl/documents/ policy-notes/2015/12/14/national-water-plan-2016-2021.
} 
2016-2021 North Sea Policy Document (which is an integral part of the National Water Plan), ${ }^{168}$ and the 2050 North Sea Spatial Agenda. ${ }^{169}$

Pursuant to the Dutch Water Act, ${ }^{170}$ which entered into force in 2009, the government is required to draft a formal water plan every six years. Accordingly, the first National Water Plan (NWP) was adopted in 2009, ${ }^{171}$ the second NWP for the period 2016-2021 was adopted in December 2015. With regard to the North Sea, the NWP entrusts the government to ensure a sustainable and spatially efficient use of the North Sea while considering the status of the marine ecosystem as required in the Water Framework Directive, the Marine Strategy Framework Directive, and the Birds and Habitats Directives. The aim of the NWP is to protect and develop the marine ecosystem. Within international frameworks, the Cabinet prioritises the following activities that are deemed to be of national importance to the Netherlands:

- Sand extraction and replenishment: sufficient space for sand extraction for protecting the coast, counteracting flood risk and for fill sand on land;

- Renewable (wind) energy: space for 6,000 MW of wind energy on the North Sea in 2020 (at least 1,00o km2), creating conditions for further (international) growth after 2020);

- Oil and gas recovery: as much natural gas and oil as possible is to be recovered from Dutch fields in the North Sea so that the resource potential in the North Sea is used to the full;

- $\mathrm{CO} 2$ storage: sufficient space for the storage of $\mathrm{CO} 2$ in empty oil and gas fields or in underground water-retentive soil strata (aquifers);

- Sea shipping: a system of traffic separation schemes, clearways and anchoring areas allowing safe and prompt handling of shipping;

- Defence areas at sea. ${ }^{172}$

168 The Dutch Ministry of Infrastructure and the Environment and the Dutch Ministry of Economic Affairs, Policy Document on the North Sea 2016-2021 (December 2015), https:// www.government.nl/documents/policy-notes/2015/12/15/policy-document-on-thenorth-sea-2016-2021-printversie.

169 Ministry of Infrastructure and Environment and Ministry of Economic Affairs, North Sea 2050 Spatial Agenda (July 2014), https://www.noordzeeloket.nl/en/Images/North\%20 Sea\%202050\%20Spatial\%2oAgenda_LO\%2oRES_3562.pdf.

170 Act of 29 January 2009, Water Act, Official Journal 2009, 107.

171 State Secretary for Transport, Public Works and Water Management and the Ministers for Housing, Regional Development and the Environment and for Agriculture, Nature and Food Quality, National Water Plan 2009-2015 (22 December 2009) p. 16.

172 National Water Plan 2016-2021 (n 167) at p. 47. 
In the 2016-2021 North Sea Policy Document, North Sea policy has been further elaborated. The North Sea Policy Document describes the changing use of the North Sea and emerging interests in the North Sea. The following issues are described: sand extraction, energy, shipping, fisheries, defence, tourism and recreation, cables and pipes, and relevant spatial development on land and the marine ecosystem. In addition, this North Sea Policy Document provides for an integrated assessment framework for all activities occurring within the North Sea.

This integrated assessment framework is the mechanism that the decisionmaking authorities use to ascertain whether activities at sea are permitted. The integrated assessment framework combines relevant policies and outlines how decisions on new activities should be made within the European and international frameworks. It also outlines which action to take if various activities of national importance conflict. The assessment framework is a policy regulation and obliges the competent decision-making authority to act in accordance with this framework when issuing permits. The assessment framework applies to all activities in the North Sea that require a permit under all laws and regulations governing the North Sea, both in the territorial sea and the exclusive economic zone (Water Act, Earth Removal Act, Nature Conservation Act, Flora and Fauna Act, Environmental Management Act, Wind Energy at Sea Act, a number of shipping acts and the Mining Act). ${ }^{173}$ As such, it is particularly important for North Sea users who want to apply for a permit and for licensing authorities. It is also instrumental in achieving and maintaining good environmental status under the Marine Strategy Framework Directive.

An innovation of the integrated assessment framework is that it moves from a reactive towards a proactive approach for the authorisation of activities. Whereas the implementation of spatial policy earlier began with a formal application for a permit, the process now often begins with consultation between stakeholders and ends with a formal decision on (spatial) management frameworks and/or permits. The formal granting of the permit is actually the end of the process. An important result of this change is the designation of particular activities of national importance, in order to ensure protection of the marine ecosystem and for the implementation of Natura 2000. ${ }^{174}$ Three important examples are: management plans for Natura 2000 sites; a sand extraction strategy

173 Policy Document on the North Sea 2016-2021 (n 168) at p. 11.

174 Interdepartmental Directors' Consultative Committee North Sea 'Integraal Beheerplan Noordzee 2015 -herziening' [The Integrated Management plan for the North Sea 2015revision] (11 November 2011) pp. 4-5. 
within the 12-mile territorial zone; and space allocation within the designated wind power areas. ${ }^{175}$

The integrated assessment framework requires the following five assessments to be carried out when a permit is to be issued:

1. The spatial claim has to be defined and the precautionary principle has to be applied. The spatial claim contains the area needed for the activity. The precautionary principle applies to all North Sea activities. ${ }^{176}$ This principle entails that a user should take preventive measures when there is reasonable doubt about the possibility that the activity could cause irreversible damage to the marine environment, human health, or other legal uses of the area. The causal relationship between the cause and the damage does not need to be proven by scientific evidence in order for the precautionary principle to apply.

2. The assessment of choice of location and use of space is a fixed part of all location-based activities subject to permitting everywhere in the North Sea, regardless of whether the activity is for a new or an existing function. This assessment is intended to prevent fragmentation and inefficient use of space. In principle, it also prevents conflicts arising between functions. With regard to oil exploitation, there usually is little margin with regard to the choice of the boring location given the fact that the drilling site needs to lie as much as possible directly above the underground.

3. The usefulness and necessity assessment is intended to prevent undesirable use. The initiator must clarify why the activity has to take place in the North Sea. In the case of new permit applications for existing functions, applicants can usually refer to existing policy in which the government sets out clear guidelines about usefulness and necessity. For instance, as explicitly stressed in the IMP2015 and the National Water Plan, the exploration and exploitation of oil and natural gas takes place for imperative reasons of overriding public interest. Being designated as such, a usefulness and necessity assessment is therefore not required.

4. When an activity has significant negative effects, the initiator has to take mitigating measures to reduce these effects. The initiator has to submit a plan providing details about these mitigating measures.

175 Ibid., para. 3.1.

176 Policy Document on the North Sea 2016-2021 (n 168) at pp. 97-103. 
5. The assessment regarding the reduction of negative effects and compensation applies to all activities subject to permitting. First and foremost, effects on ecological features must be limited. If there is a significant impact, there must be compensation in the form of restoration of comparable ecological features elsewhere. However, there is a threshold: in the case of activities for which an environmental impact assessment is not obligatory, the competent authority assumes that the impact is insignificant. In the case of activities that do require an environmental impact assessment report, the effects on ecological features and the environment will be set out in that report. ${ }^{177}$

From the European perspective, the Maritime Spatial Planning Directive requires use of space at sea to be planned. International cooperation is key in this regard, and special attention is paid to the connection between land and sea. Although the Maritime Spatial Planning Directive does not legally have to be implemented before 2016 and an initial maritime spatial plan will be established by March 2021 at the latest, the National Government has already acted in accordance with the requirements of the MSPD when formulating the North Sea Policy Document. In addition to outlining the policy, the North Sea Policy Document, as an independently readable appendix to the NWP, also includes a framework vision map and therefore constitutes the Dutch maritime spatial plan. ${ }^{178}$

\section{Environmental Law in the Netherlands}

Environmental law applicable to the Dutch part of the North Sea is fragmented though a process of harmonisation has been going on in the last decade. This body of environmental law consists of a number of general laws, sector laws and nature conservation laws.

Two important general acts which apply within the territorial zone are the 1993 Environmental Management Act ${ }^{179}$ and the 2008 Environmental Licensing Act. ${ }^{180}$ The Environmental Management Act provides for an integrated approach to environmental management in the Netherlands as it intended to integrate different types of pollution and nuisance control under

177 Policy Document on the North Sea 2016-2021 (n 168) at pp. 97-103.

178 Policy Document on the North Sea 2016-2021 (n 168) at p. 16.

179 Act of 2 July 1992, Environmental Management Act, Official Journal 1992, 551.

180 Act of 6 November 2008 'Environmental Licensing (General Provisions) Act, Official Journal 2008, 496 (first text) and Official Journal 2010, 231 (entry into force). 
one statute. It regulates the use environmental plans, the establishment of environmental quality criteria for emissions and discharges of harmful substances, the execution of environmental impact assessments as a prerequisite for the construction of major infrastructure such as oil refineries, nuclear power plants, chemical plants, roads, railways, and oil and gas pipelines and the issuing of environmental permits, among others. ${ }^{181}$

The 2008 Environmental Licensing Act combines 25 previous permit systems that relate to the physical social environment under one single act. ${ }^{182}$ These systems regulate building permits, demolition permits, mining permits, environmental permits and permits relating to monuments and historic buildings plus various exemptions from zoning plans and permits based on the Nature Conservation Act 1998. Therefore, this Act goes beyond the scope of coordination as it integrates decision-making into one procedure and under the responsibility of one competent authority, even though the standards of the specific permit systems are still listed separately. ${ }^{183}$ Instead of various parallel permits from various government agencies, there is now only one umbrella permit required: the local environment permit. Such an umbrella permit makes the procedure much more transparent and simple. ${ }^{184}$ Even so, there is no substantive integration; the individual checks and balances to which individual permits are subject - and which are currently embedded in various laws—remains intact. ${ }^{185}$ The Environmental Licensing Act only applies to the territorial zone. Licences required for activities taking place outside of the territorial zone have to be granted pursuant to the relevant sector legislation. ${ }^{186}$

181 See further Government of the Netherlands, 'Environmental Management Act' available at: http://www.government.nl/issues/environment/roles-and-responsibilities-of-centralgovernment/environmental-management-act; accessed 13 October 2016. Chapter 7 of the Act on Environmental Impact Assessment also applies to the exclusive economic zone.

182 This also comprises permit systems of the Environmental Management Act and the Spatial Planning Act.

183 MA Heldeweg and RJGH Seerden, Environmental Law in The Netherlands (Kluwer, Dordrecht, 2012) at p.46.

184 A Blomberg, $\mathrm{T}$ de Gier and J Robbe, 'The integration of the protection of nature conservation areas in Dutch spatial planning law and environmental management law' (2009) 5(1) Utrecht Law Review 132-157, at p.153.

185 Ibid.

186 P Drankier and AG Oude Elferink, Identificatie en analyse van relevante regelgeving en beleid in het kader van het project "Beleid en regelgeving informatiesysteem Noordzee" (BREIN); Herziening 2011 (Netherlands Institute for the Law of the Sea (NILOS), Universiteit Utrecht, 2012) at pp. 38-39. 
For spatial planning, the 2008 Spatial Planning Act ${ }^{187}$ and the Crown Decree on Spatial Planning 188 are important. The Spatial Planning Act aims to achieve more efficient decision-making, improved enforcement and more simplified legal protection in spatial planning. In addition, the Act allows for designing spatial zoning plans including for the North Sea. ${ }^{189}$ The Spatial Planning Act has widened the scope of what may be covered in spatial plans. Earlier, the limitations on what may be regulated by the spatial planning legislation were fairly strict. This made co-ordination between spatial planning and some other policy sectors (in particular, environmental policy) difficult. In this Act, those limitations are reduced and there is more room for taking into account policy concerns from other sectors. For example, environmental norms can be included in a land-use plan. Those changes should make it easier to integrate spatial planning with policies from other sectors. ${ }^{190}$ The Spatial Planning Act also applies to the territorial sea and the exclusive economic zone. ${ }^{191}$

Besides these general acts, a large number of sector acts exist that regulate different activities in the territorial sea and the exclusive economic zone such as mining, ${ }^{192}$ fisheries, ${ }^{193}$ excavation, ${ }^{194}$ and offshore wind energy production. ${ }^{195}$ In contrast to Norway, the principle of environmental policy integration has not been implemented as strongly in the Netherlands. Most sector laws do not contain any provisions that refer to the need to take environmental considerations into account, nor do they explicitly refer to any environmental principles. The argument against codification of environmental principles is that it would have little added value since they are codified by the legislation of the European Union, are acknowledged in international environmental law, and will therefore have legal effect in the Dutch legal order. ${ }^{196}$

187 Act of 1 July 2008, Spatial Planning Act, Official Journal 2008, 227.

188 Crown Decree of 21 April 2008 on spatial planning, Official Journal 2008, 145.

189 Article 10.3 of the Spatial Planning Act.

190 B Needham, 'The New Dutch Spatial Planning Act: Continuity and Change in the way in which the Dutch regulate the practice of spatial planning' (2004) 12 University of Nijmegen Working Paper Series, at p. 11.

191 Article 1.1, paragraph 2 (a) Spatial Planning Act.

192 Act of 31 October 2002 concerning Mining Activities, Official Journal 2002, 542.

193 Act of 30 Mai 1963 concerning fisheries, Official Journal 1963, 312.

194 Act of 27 October 1965 concerning the extraction of minerals, Official Journal 1971, 520.

195 Act of o1 July 2015 concerning the production of offshore wind energy, Official Journal 2015, 261.

196 K de Graaf, FM Platjouw and HD Tolsma, 'The future Dutch Environment and Planning Act in light of the ecosystem approach' (2017) 23 Ecosystem Services part A. 
Environmental law in the Netherlands could perhaps be better described as following the principle of environmental policy disintegration. The tradition of not regulating any matters that are already regulated in other existing legislation results in the protection of nature being mainly regulated by the nature conservation legislation. As will be shown, nature conservation legislation in the Netherlands is rather strict.

Nature areas and flora and fauna in the Netherlands are protected under the 1998 Nature Conservation Act ${ }^{197}$ and the 1998 Flora and Fauna Act. ${ }^{198}$ Both can be regarded as the Netherlands' implementation of the European Birds and Habitats Directives. The Nature Conservation Act lays down requirements for the preservation of nature areas, while the Flora and Fauna Act focuses specifically on the protection of plant and animal species. The Nature Conservation Act establishes rules for the designation of nature areas of outstanding national or international importance as nature reserves and Natura 2000 areas, ${ }^{199}$ respectively. It also regulates which activities are allowed in protected nature areas and under which conditions. The Flora and Fauna Act stipulates protection regimes for certain plant and animal species regardless of whether they occur in nature reserves or not. It contains a general duty of care for all wild living animals and plants, including their direct living environment. ${ }^{200}$ If an activity will affect any of these protected animals or plants or their habitat, an exemption from the general prohibitions may be applied for. The Nature Conservation Act and the Flora and Fauna Act have been under amendment and their geographical scope was extended out to the exclusive economic zone beginning 1 January $2014 .^{201}$

Currently, the Dutch government is working on a legislative project that will fundamentally change the structure of Dutch environmental law: the Environment and Planning Act (hereafter EPA). Although the E PA has already been adopted, it will not enter into force before all necessary implementing legislation is adopted, possibly in 2019. One of the main reasons for the

197 Act of 25 Mai 1998 containing rules for the protection of nature and landscapes, Official Journal 1998, 403 .

198 Act of 25 May 1998 containing rules for the protection of wild living plants- and animal species, Official Journal 1998, 402.

199 The European Natura 2000 network consists of Special Protected Areas (SPA) designated under the Birds Directive and Special Areas of Conservation designated under the Habitat Directive.

200 Art 2 of the Flora and Fauna Act.

201 Act of 9 October 2013 amending the Nature Conservation Act 1998 and the Flora and Fauna Act in connection with the expansion of the scope of these laws to the exclusive economic zone' [2013] Official Journal 2013, 412. 
fundamental change is the idea that current and future challenges concerning the use and protection of the environment cannot be tackled effectively using current legal instruments, which are found across a large range of statutory regulations. At the national level there are approximately 4700 provisions spread over 35 Acts, 120 governmental decrees (Orders in Council), and 120 ministerial decrees. The transition towards a sustainable society requires a structural change, because current legislation and instruments do not focus sufficiently on sustainable development. The EPA will replace 15 existing legislative acts covering environmental law, including the General Act on Environmental Permitting, the Water Act, the Spatial Planning Act and the Crisis and Recovery Act, and incorporate the area-based components of eight other acts, such as the Environmental Management Act (Parliamentary Papers II, 33962, No. 186). ${ }^{202}$

\section{Findings and Reflections on the Need for Transboundary Marine Spatial Planning-Reason to Worry?}

Although Norway and the Netherlands are both North Sea neighbouring states, they are very different in terms of demography and geography, geopolitical interests, policy strategies and legislative structures. The Netherlands is a lowlying country, which necessitates a focus on the protection of dikes through excavation activities. The Netherlands has also a relatively shallow North Sea area, which provides opportunities for offshore wind energy production. The North Sea Policy Document 2016-2021 emphasizes that these two activities are of primary national importance. In contrast, the seafloor under Norwegian jurisdiction is much deeper, making it much more complex and expensive for wind energy. In addition, the Norwegian seabed contains huge amounts of petroleum, which has resulted in a political and industrial focus on the exploitation of petroleum. These geographical and geopolitical differences have led to different priorities and interests for the North Sea in the two counties.

Another important difference between Norway and the Netherlands is related to the body of law applicable to their 'parts' of the North Sea. As mentioned above, most of the EU environmental directives such as the EU Habitats and Birds Directive, Marine Strategy Framework Directive, and the MSP Directive do not apply in Norway. This is most relevant in terms of how human activities are balanced with environmental protections. In the Netherlands, environmental protections are facilitated through the designation plan as laid down

202 De Graaf, Platjouw and Tolsma (2017) (n 196) at p. 1. 
in the 2016-2021 North Sea Policy Document, the Natura 2000 network and the strict rules of the nature conservation laws. Through the extension of the geographical scope of the nature conservation legislation, nature conservation in the exclusive economic zone will now be subject to the stringent requirements of the Nature Conservation Act and the Flora and Fauna Act. This may ensure a better balance between the sustainable use of the ecosystem and the maintenance of ecosystem integrity throughout the exclusive economic zone. At the same time, it may provide greater consistency because the impacts of the various activities can be assessed against the rules of one specific legal act, rather than have these assessments take place in the context of the several different sectoral legal acts.

Environmental law and governance in Norway can be characterized by the principle of Environmental Policy Integration, which requires environmental issues moving from the periphery to the centre of decisionmaking, integrating them in the very design and substance of sectoral policies. ${ }^{203}$ Though this might contribute to sustainable development, there is also a risk of a variety of approaches across sectors, which might practice environmental integration differently. As Bugge notes

The different authorities weigh and balance their sector objectives against the related environmental effects differently. Environmental values are not treated consistently across sectors. The environment becomes a 'consideration' which is given different weight by different authorities, on a case-by-case basis. ${ }^{204}$

At first glance this case-by-case approach appears to be difficult to align with the more proactive approach practiced in the Netherlands. Jay and others correctly suggest that transboundary MSP initiatives need to take into account not just geographical and ecological dimensions of shared sea areas, but also the cultural, social, policy and governance variations of different jurisdictions. ${ }^{205}$ These differences in legal structures and traditions may well impede the drafting and implementation of plans for transboundary marine spatial planning

\footnotetext{
203 European Environment Agency, Environmental policy integration in Europe. State of play and an evaluation framework (26 May 2005) Technical Report No. 2-2005, at p. 12.

204 HC Bugge, 'Environmental law's fragmentation and discretionary decision-making. A critical reflection on the case of Norway' in E Røsæg, HB Schäfer and E Stavang (eds), Law and Economics: Essays in Honour of Erling Eide (Cappelen Damm Akademisk, Oslo, 2010) 8-12, at p. 9 .

205 Jay et al. 2016 (n 124) at p. 87.
} 
because certain legal and institutional traditions are deeply rooted and likely difficult to adapt. Yet, the ideology behind the need for transboundary MSP and the necessity of maintaining the ecological integrity of our marine ecosystems should incentivize countries to look beyond jurisdictional boundaries and national traditions that initially may seem to vindicate specific domestic approaches to the governance of 'their' parts of the North Sea ecosystem.

To conclude, this article has shown that transboundary cooperation in marine regions might be challenging when common national and supranational legal frameworks are lacking. Norway and the Netherlands do have a divergence in national policies and legal structures for MSP. Though the MSFD and the MSPD require cooperation with third countries such as Norway, so far this cooperation has been limited to the development of joint indicators for the monitoring of the marine environment under the framework of the MSFD, with no joint work under the MSPD. At present, experiences with transboundary MSP in the North Sea are thus limited to an exchange of information. ${ }^{206}$ Transboundary management plans could play an important role in overcoming the challenges of fragmentation and the lack of common legal frameworks. Similar to the Dutch integrated assessment framework, a harmonizing transboundary decision-making framework could be designed for the management of the North Sea.

206 A Kannen, 'Challenges for marine spatial planning in the context of multiple sea uses, policy arenas and actors based on experiences from the German North Sea' (2014) 14 Regional Environmental Change 2139-2150, at p. 2147. 